
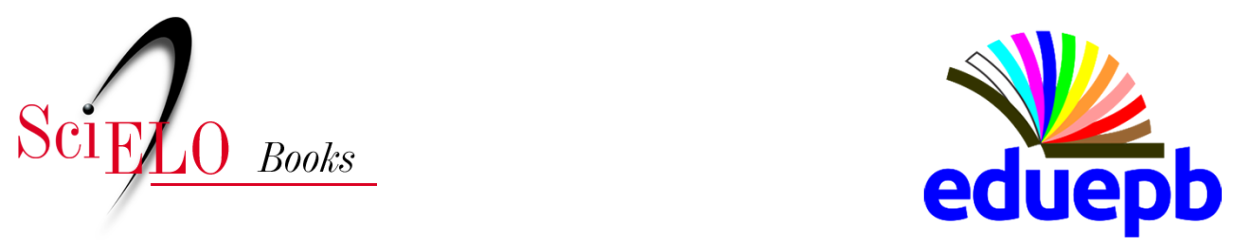

\title{
Historical Inquiry Cases in a Brazilian Context
}

\author{
Douglas Allchin
}

\section{SciELO Books / SciELO Livros / SciELO Libros}

ALLCHIN, D. Historical Inquiry Cases in a Brazilian Context. In: SILVA, A. P. B., and MOURA, B. A., eds. Objetivos humanisticos, conteúdos científicos: contribuições da história e da filosofia da Ciência para o ensino de Ciências [online]. Campina Grande: EDUEPB, 2019, pp. 179-203. ISBN: 978-85-78795-79-5. http://doi.org/10.7476/9786586221664.0006.

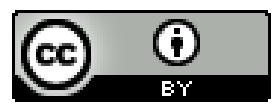

All the contents of this work, except where otherwise noted, is licensed under a Creative Commons Attribution 4.0 International license.

Todo o conteúdo deste trabalho, exceto quando houver ressalva, é publicado sob a licença Creative Commons Atribição 4.0.

Todo el contenido de esta obra, excepto donde se indique lo contrario, está bajo licencia de la licencia Creative Commons Reconocimento 4.0. 


\title{
HISTORICAL INQUIRY CASES IN A BRAZILIAN CONTEXT
}

\author{
Douglas Allchin \\ University of Minnesota \\ allch001@umn.edu
}

\section{Introduction: From History to Inquiry}

eaders of this volume are likely already familiar with
the value of enriching science education with history
(ALLCHIN, 2013; CONANT, 1947; KLOPFER ,1969; NASH 1951). For advocates, the enduring challenge is practical, not theoretical: realizing the goal by persuading others, preparing curriculum materials, teachers and assessment instruments, and ultimately integrating history among institutional goals and daily practice (ALLCHIN, 2012; HENKE; HÖTTECKE, 2015; HODSON, 2008; HÖTTECKE; SILVA, 2012; MONK; OSBORNE, 1997).

Over the past few decades, the environment has changed significantly. Notably, in 1996 the U.S. National Science Education Standards (NATIONAL RESEARCH COUNCIL, 1996) designated "history and nature of science" as an essential feature of scientific literacy (echoed by Rutherford and Ahlgren (1990)). That focus spread internationally (MCCOMAS; OLSON, 1998). Ironically however, while historical perspectives of science were largely responsible for the shift in philosophical views in the 1970s and 80s that fueled this change, history has faded as an explicit element. What remains is robust support for teaching 
about the nature of science, or NOS (NGSS LEAD STATES, 2013; OSBORNE et al., 2003; OECD, 2017).

While NOS has taken a comfortably strong institutional foothold, history itself remains largely peripheral. The trending theme now is inquiry, or scientific practices: educators want students to conduct their own investigations (DENG et al., 2011; NGSS LEAD STATES 2013). Teachers have largely welcomed the strategy, although mostly because it helps engage students. Accordingly, a fruitful approach for conveying historical perspectives seems to be integrating them with inquiry (ALLCHIN, 2012; in press 1; BRUNEAU et al.,2012; HIPST, 2008; RUDGE; HOWE, 2009).

Even more, however, one can view history as improving or facilitating inquiry itself (ALLCHIN, in press 2; see Table 1). First, history can help motivate questions through human and cultural context (IRWIN, 2000; STINNER, 1995; STINNER et al., 2013). Second, it can help problematize meta-level questions for deeper nature-of-science learning (ALLCHIN; ANDERSON; NIELSEN, 2014; ALLCHIN, 2013; CLOUGH, 2006; HOWE, 2007). Next, historical cases render the uncertainty of sciencein-the-making, basic to learning how conclusions derive from evidence, not the other way around (FLOWER, 1995; LATOUR, 1987). A historical lineage of questions also helps structure inquiry (through an episodic, or "interrupted," narrative) (FARBER, 2003; HERREID, 2005). The narrative format itself is engaging and also provides a trajectory that leads to a secure resolution of inquiry, which is inherently open-ended (CLOUGH, 2011; HAGEN; ALLCHIN; SINGER, 1996; KLASSEN, 2007). All these elements should interest the inquiry teacher who is not yet attuned to the virtues of history. Highlighting the links specifically between inquiry and history will help enhance practicing teachers' views of the value of history. 
Table 1. Features of the episodic historical inquiry model (ALLCHIN, in press).

(1) Motivate inquiry through both cultural and biographical historical contexts

(2) Problematize the nature of science through puzzles and questions

(3) Foster inquiry and the uncertainty of science-in-the-making through historical perspective

(4) Structure inquiry stepwise to follow a historical lineage of questions, linked through an episodic ("interrupted") narrative

(5) Resolve the scientific inquiry and historical narrative in tandem

(6) Consolidate NOS lessons through a final and explicit reflection

(7) Use the narrative format to provide a historical explanation of NOS

Here, I present a few examples of this strategy for teaching NOS: framing historical episodes as student inquiry cases, or science-in-the-making. Each contains a series of inquiry questions motivated by and structured by historical context, threaded together by historical narrative, and designed to foster reflective nature-of-science thinking (ALLCHIN, in press 2).

These cases also exhibit another feature attractive to most teachers, which further enhances the likelihood that history is adopted in actual classroom practice: they help celebrate local scientific achievements - in this case, Brazilian science. (Fortunately for Brazilians, they are also written in Portuguese!) Of course, this local orientation is not essential to understanding the nature of science. But for teachers, who often decide what happens in their classroom, national pride and the prospect of providing local role models for students are potent motivators.

\section{Vital Brazil and Snake Venom}

The first case is about Vital Brazil (Figure 1), who discovered the specificity of snake venom and went on to help establish the Butantan Institute, now one of the world's leading research institutes on immunotherapy and animal toxins (ALLCHIN, 
2017; RICCI; DE OLIVEIRA, in press; RICCI; TEIXEIRA; DE OLIVEIRA, in press).

Figure 1. Vital Brazil (courtesy of Butantan Institute).

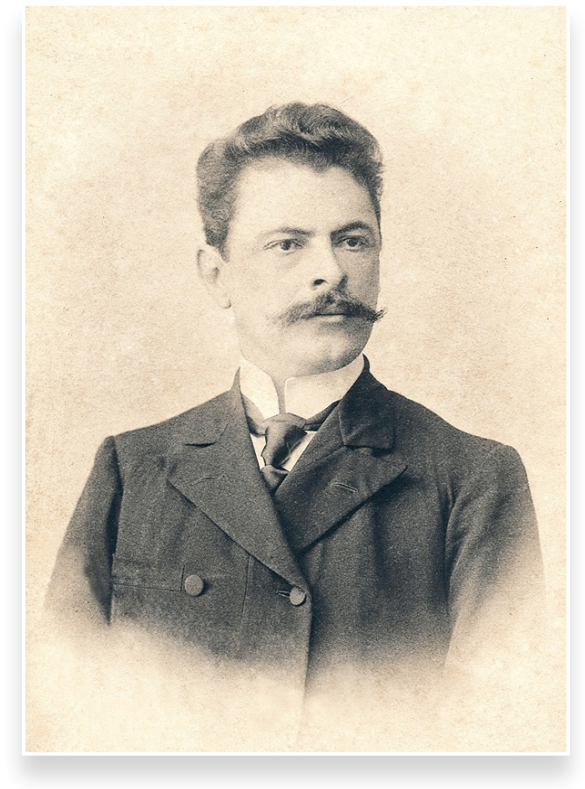

The first feature of historical inquiry is a cultural and personal context for motivating investigation. In this case, we situate ourselves in the 1890s: Imagine how nearly three thousand persons are dying annually in Brazil due to encounters with venomous snakes. Many are illiterate immigrants working on coffee plantations or building the railroads that help transport the coffee. Few doctors are available in rural areas. Workers rely primarily on local healers with their herbal remedies. But are they truly effective? Our motivation, then (still in the 1890s), is healing snake bites - effectively. 
Now we add the personal dimension: Young physician Vital Brazil Mineiro da Campanha worked in the town of Botucatu, São Paulo state. He wanted to systematically test those alleged treatments.

Second, the case focuses on particular problems with particular corresponding lessons in nature of science. For example, to test remedies, Vital Brazil needs test animals. Fortunately for him, dogs, goats and guinea pigs are readily available. But what about securing the test venom? Hypothetical snake venom does not work. You need living creatures. Along with their real dangers. And Brazil is deeply afraid of snakes. How will you get the snakes? How will you extract the venom?

Here we meet science-in-the-making - historical inquiry feature \#3. While an easy answer might be found today on Google or Wikipedia, the students must address the challenge themselves. No clues. No prior knowledge. This engagement with uncertainty and creativity is the core of inquiry learning.

After the students generate and discuss their responses, we turn back to Vital Brazil. He works with local healers to get snakes-living snakes that have been captured, rather than immediately killed as a threat. The first two specimens are mishandled and soon die. If you need snakes, a seemingly trivial task like the proper handling of snakes can ultimately be essential to practicing science. The third snake survives. Next, Brazil presents his snake with a fake target: a mass of cotton, into which it releases its venom. Much later, the director of a research institute helps develop a long-handled device for lassoing the snakes, now known as Lutz's loop (Figure 2). With all the supplies and specimens in hand, the task of administering remedies and comparing them is relatively simple. But note the nature of science lesson here: science needs concrete - and sometimes risky-work in the material world. It's not just about theories or imagining ideal experiments on paper. 
Figure 2. Lutz's loop (courtesy of Butantan Institute).

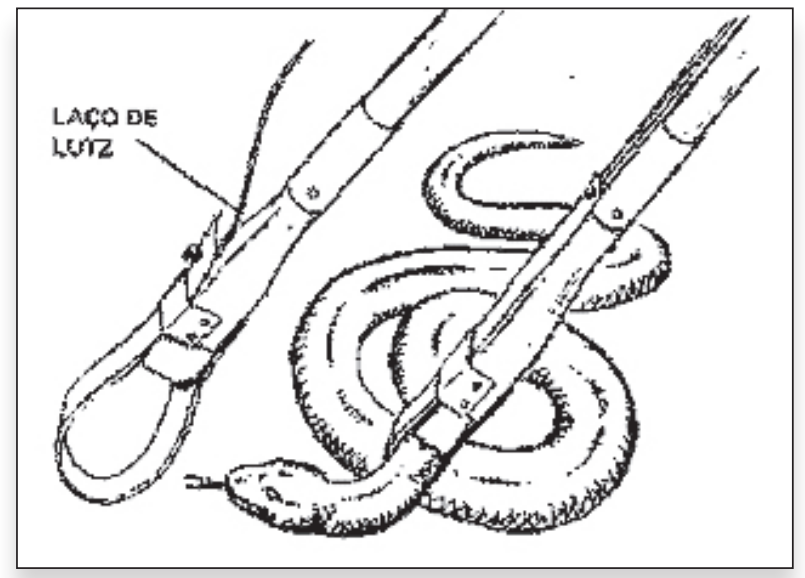

Of course, the investigation is not complete. But where do you go next? Student-led inquiry can be somewhat blind and haphazard if one is not careful. If it is too pre-ordained, students feel manipulated, and simply wait for answers, losing the core lessons of uncertainty and science-in-the-making (HENKE; HÖTTECKE, 2015). So (historical inquiry feature \#4), we follow Vital Brazil along a lineage of questions that emerge naturally in a narrative format. When Brazil finds (not surprisingly, perhaps) that none of the local remedies are effective, he consults elsewhere. He reads about work in Europe that indicates a role for anti-sera, a new approach to medicine. You immunize animals to snake bites, then extract their blood serum to treat other organisms that had been bitten. The dominant theory ranks the toxicity of the various species, meaning that sera from the most venomous snakes should work against all. Vital Brazil is eager to get some cobra venom, the strongest. But it all comes from France and is very expensive. When he finally secures some and tests it, he finds it has no effect at all on Brazilian snakebites. So he will have to make serum in Brazil. But that now needs a fancy lab. 
Brazil finds a new job and relocates to a bacteriological institute in the capital city of São Paulo, where the director allows him time-and resources-to continue his interest in snake bites. He begins collecting several species of poisonous snakes and immunizing animals to develop anti-sera. He looks for the strongest venom, but the results are unexpected. Now it is the students' turn again, to examine and interpret the findings. The rattlesnake anti-sera work on rattlesnake venom, but not on jaracara venom. Likewise, the jaracara serum work only on jaracara bites, not rattlesnake bites. Students generally are able to conclude along with Brazil that sera are species specific, not ranked from weakest to strongest. You need serum from the snake species that bit you. At that time, the discovery of immunological specificity of snake venoms had global significance, changing how immunologists conceived poisonous venoms, not just in snakes. And students are able to share vicariously in the discovery. That's historical inquiry feature \#7: the role of an experiential narrative, or storytelling format, in helping to convey an abstract explanation.

So, to prevent snake bites, Brazil needs to make sera for each snake type. More snakes, more lab resources. For a while, Brazil is prevented from doing much. Plague has broken out in a nearby port and his job is to make anti-sera. That takes priority. But it all proves a benefit eventually. To be able to produce large quantities of plague anti-sera, the government institute purchased a large farm outside the city (Figure 3) to maintain the horses and sheep that functioned as organismal "factories" for the serum. When Brazil resumes his work on snake venom two years later, he has the extra resources he needs. But now Brazil needs even more snakes, and a place to keep them all while occasionally harvesting their venom. Another problem for students: part of the historical lineage of questions. 
Figure 3. Fazenda Butantan (courtesy of Butantan Institute).

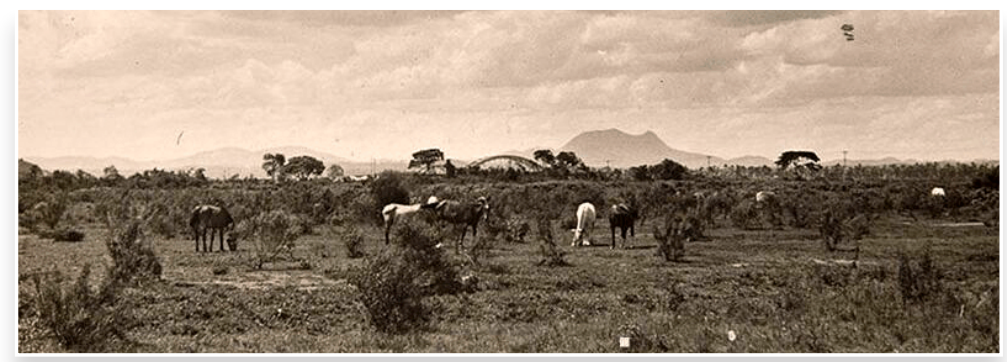

Where do you keep snakes safely? Brazil constructs a large serpentarium, surrounded by a pit and sheer walls. In time, the small "snake zoo," with its thrilling proximity to danger, becomes a popular attraction for visitors.

At the same time, Brazil creates an exchange system for keeping an adequate stock of snakes and then distributing the sera. When workers in rural areas ship him a snake in one of the heavy wooden boxes that the institute provides, he returns several bottles of serum and syringes for the treatment of snake bites. Establishing that system helps transform an ideal of potential treatment into a sustainable reality. Mortality rates from snakebites drop from $25 \%$ to $2 \%$. This is science in action and it exhibits substantive work and resources, not just abstract scientific reasoning alone.

Vital Brazil works over the next several years to transform the old farm into the Butantan Institute, which has become today one of the most important worldwide research centers in immunology, the production of vaccines and anti-sera, and other biopharmaceuticals. Historical inquiry feature \#5: "happy ending" and resolution. The original scientific problem of healing snakebites is solved, and the personal and cultural story comes to a satisfying end. 
That is an opportunity to review, and consolidate learning about the nature of science. This case illustrates (repeatedly) that scientific ideas are one thing, but without the institutions and resources that materially enable research, science is empty. The image of the serpentarium, which became a popular tourist destination celebrated in postcards, helps underscore the indispensable role of infrastructure in science (Figure 4).

Figure 4. Serpentarium (courtesy of Butantan Institute).

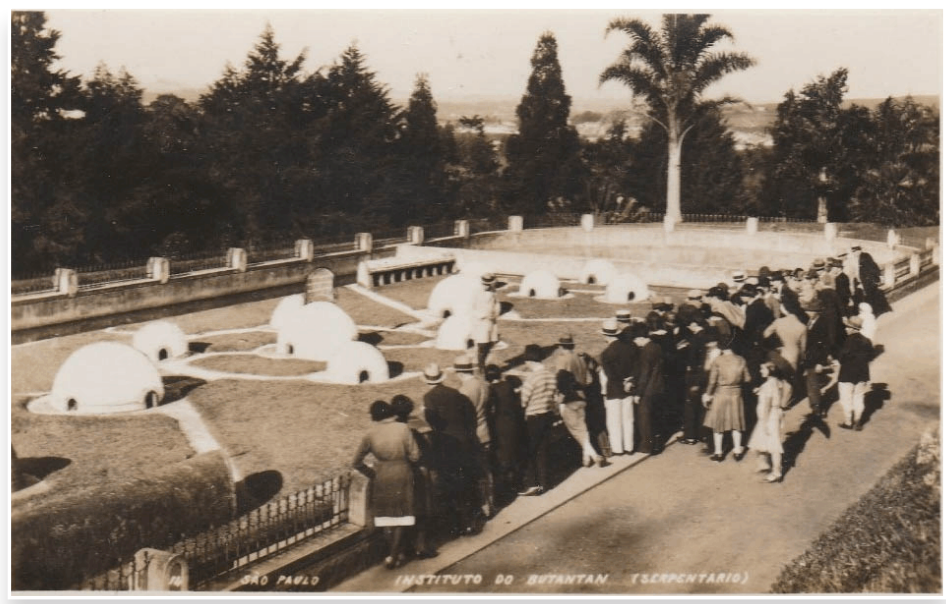

So, the case of Vital Brazil profiles a scientist of international caliber, but also a Brazilian hero. It is also a story of science solving Brazilian problems, but with a globally significant solution. The local connection can make the science seem more relevant and important to Brazilian students - and so contributes to the core problem of motivation and engagement in learning about science. 


\section{Carlos Chagas and the Railroad Workers Disease}

A second case also illustrates the historical inquiry model. And it involves a scientist that most Brazilians know by name (AZEVEDO; DEL CORSO, in press). Yet few know much about his research in much detail. So it provides another opportunity for profiling the nature of science, but in this case with the name suppressed. The questions and unknowns are foremost to revive science-in-the-making (\#3), even though events have already happened.

The initial problem is, again, a disease among the railroad workers (\#1) early last century. A young physician is sent to the countryside to treat patients. At first, the disease looks like malaria, but also not exactly like malaria. Students must analyze the list of symptoms of each and decide: Is the disease merely a variant of malaria, to be treated the same way, or is it something new, which may require a different treatment?

Further observation indicates that in later stages, the patients develop enlarged thyroid glands (Figure 5). Is the disease a form of goiter? Again, the students must review the symptoms and decide. They must also consider, more generally, what criteria are used to classify diseases (\#2).

While visiting a remote district, our physician hears from the chief engineer of the railroad that many patients with the goiter have problems with bed bugs in their shacks. He wonders if there might be a connection. Now, the students face the NOS problem of expertise (\#2). The engineer is not a doctor. Should they trust what he says?

Just a few decades earlier, Carlos Finlay had identified mosquitoes as carriers of yellow fever, so our physician decides to investigate the bed bugs. But how do you research this? Here, the students must think about research strategies, how to organize a search, using models and hypotheses (\#2). 
Along with his colleague, our physician collects several samples of the bug. Following the example of yellow fever, he looks in the gut for microorganisms and finds a flagellated protozoa of the genus Trypsanoma. But is it the cause? Because of his interest in diseases, he also examines the blood of other animal species, and finds another form of Trypsanoma in the local marmosets. But he cannot be sure if it is exactly the same species as that found in the disease bugs. Students are again challenged to propose ways to investigate this problem (the next question in a series of inquiries, \#4).

Figure 5. The railroad workers' disease.
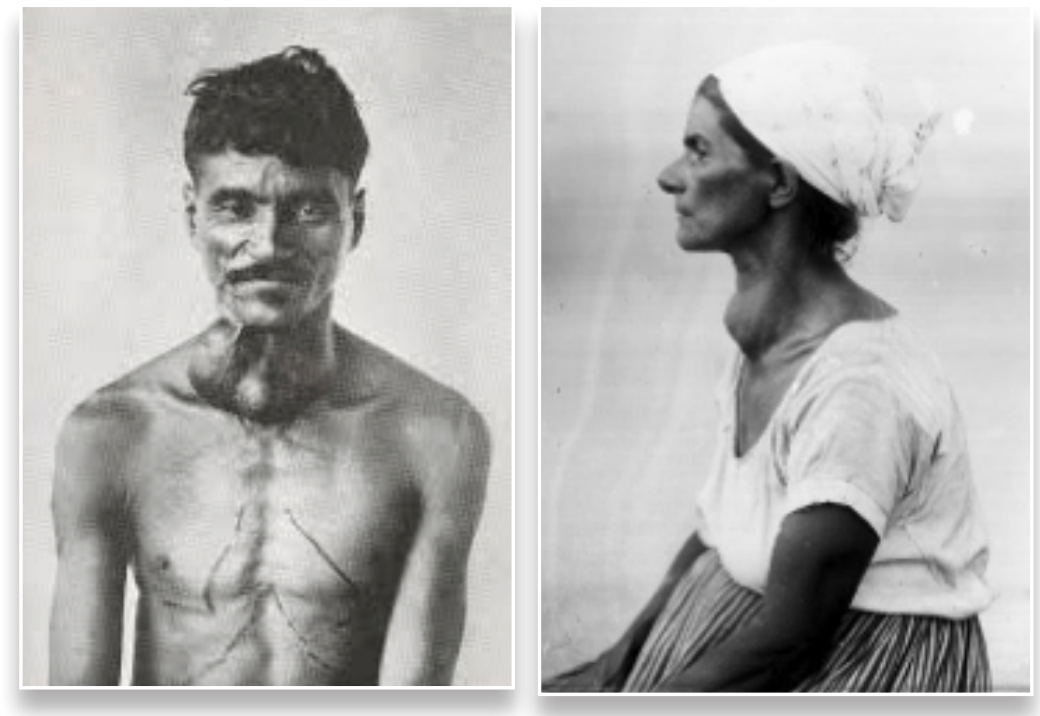

With the help of a major research institute in Rio de Janeiro, the team finds that when marmosets are infected by the bugs, they develop the new disease in 30 days, and show signs of the microorganism in their blood - but now they find it to be a new species of Trypsanoma, unlike those he found in the marmoset blood earlier. So now our physician examines blood from 
his disease patients, but they do not show the presence of bug's Trypsanoma either. Apparently, with all this work, there is no connection. So, what do you do next? This is another major dilemma for the students to solve (again, a series of questions connected by an authentic narrative, \#4,\#7).

Our physician in Brazil, Carlos, returns from the research institute to treat his patients. One young patient is severely ill, in an advanced stage. And he decides to takes another blood sample. This sample now shows the new species of Trypsanoma. So, there does seem to be a connection, after all. The microorganism must have changed its form inside the patient as the disease progressed.

In the remainder of the case, students learn about the changes in the morphology of the Trypsanoma. And they see how the microbe moves from organism to organism, via the bug, eventually to humans. The discovery of a new disease is confirmed, and named after the physician, Carlos Chagas (Figure 6) - a famous Brazilian figure many students know, although only remotely. Chagas was the first person to identify a new disease and also track down all the stages of the infection cycle, which involved the microorganism, the insect vector, and several natural hosts (\#5).

In this case, students learn about several aspects of the nature of science, which are now reviewed (\#6):

1. the role of economic factors in the work of scientists;

2. the role of personal motivations;

3. the role of the analogy between a new disease and one already known;

4. the role of local knowledge versus systematic research;

5. the role of chance in scientific discoveries;

6. the interaction of laboratory and field studies.

This case helps illustrate further the role of a lineage of questions and a sequence of inquiry episodes for the students (\#4). They follow the history of a major discovery, but in small steps. 
They participate in authentic science, not artificial or "cookbook" classroom investigations. All the answers are not obvious. The students must work with uncertainty and make conclusions based on the evidence available, rather than on already knowing (or guessing) the right answer (\#2).

Figure 6. Carlos Chagas (Wikimedia, cc2).

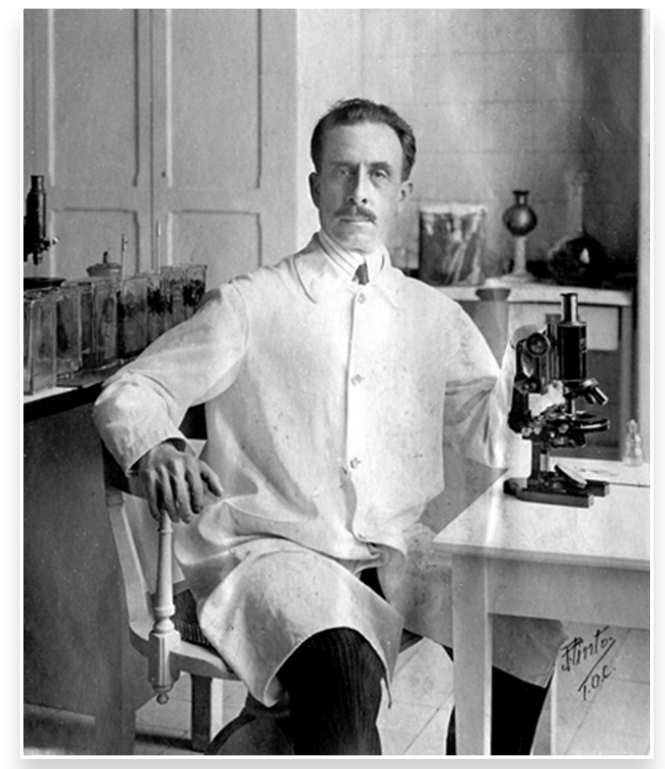

\section{Johanna Döbereiner, Soil Bacteria and Plants}

The third case in this small collection focuses on a less familiar scientist, but one of enormous economic importance to Brazil: Johanna Döbereiner (Figure 7) (PONCE; SIMONETTI, n.p.). Her work begins in the late 1950s and extends for several decades, helping to establish a role for nitrogen fixing bacteria in many tropical crops - beyond the Rhizobium bacteria in legumes that have been known for a long time. 
Figure 7. Johanna Döbereiner (courtesy Embrapa)

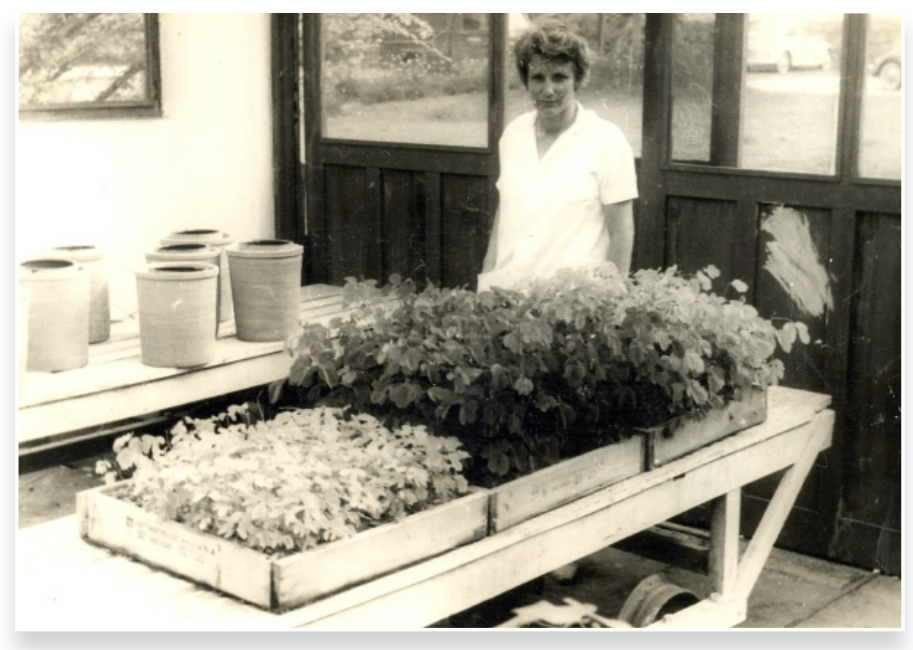

Döbereiner arrives in Brazil in the 1950s with her husband, as émigrés from Czechoslovakia. At first, she (and the students following the case) must decide if, despite her credentials and experience, she will accept an unpaid position. She ultimately accepts, allowing her to continue work on soil microbiology and agronomy. When her supervisor leaves, she is left to work on her own. She reflects on the problem of fertilizers, which are now promoted by agricultural models from the U.S. Johanna notices that some strains of plant develop even if nobody fertilizes them. For example, Bahia grass grows everywhere in Brazil without being fertilized. Sugarcane productivity can remain constant for many years without the addition of nitrogen fertilizer. Again, adopting the position of Johanna, students now speculate on possible reasons why.

With her background in soil microbiology, Johanna considers a role for independent nitrogen-fixing bacteria in the soil. One such species is Azotobacter. She can test their growth 
in Brazilian soils, but what factors here might be relevant to investigate? Students must decide. Döbereiner considers temperature first and conducts climate-controlled experiments. She concludes that higher temperature matters to Azotobacter growth. Accordingly, the numerous studies already done on Azotobacter in the temperate environments of Europe and North America are not relevant to Brazil. Location matters. Temperature was an overlooked variable.

Johanna also considers the possible role of soil acidity. Azotobacter, researchers have claimed, do not like acid soils. So (apparently) they should not thrive in the generally acidic soils of Brazil and the tropics. But Johanna also finds a few previous studies where they are found in tropical soils. Students receive one researcher's data on the percentage of Azotobacter in soil samples with different $\mathrm{pH}$ values. They look for any patterns, and compare their conclusions with those already published.Johanna must reject the widely accepted conclusions as not informed by studies in the tropics, and biased by the scientists' preferred theories.

So, based on lab studies, Azotobacter should be able to grow in Brazilian soils. But do they? Students must plan how to proceed. Now, Johanna must examine soil samples from different geographical regions within Brazil, then conduct more field experiments based on different soils inoculated with Azotobacter. They must be tested again with different conditions of temperature and acidity. Yes, they do add nitrogen to the soil, enhancing the growth of many plants. Meanwhile, some species of Azotobacter are reclassified to another genus, Beijerinckia. This opens new possibilities for considering other related species that have not yet been investigated.

Johanna now takes a few years to finish her formal degrees in the U.S. and returns to Brazil and is appointed to the National Soybean Commission. Economic conditions favor the export of soybeans, but - here is the next question - what can help increase 
production? The dominant model of agriculture is to develop improved genetic strains and make large capital investments for mechanized farming, with substantial inputs of fertilizer and irrigated water. Johanna considers instead the role of biological nitrogen fixation. Soybeans are not known to have symbiosis with Rhizobium. But Johanna is skeptical and tries several different strains of Rhizobium, finding some new ones that interact with soybeans. At first her work is disregarded as irrelevant. But as the difficulties - and expenses - of capital-intensive agriculture increase, Johanna provides an alternative to the costly use of fertilizer - which makes soybean production cheaper than in the U.S. Soybean production increases over the next several decades. By 2003, Brazil becomes the world's second largest producer of soybeans, accounting for over $1 / 4$ of the world's total. Johanna's attention to the microscopic bacteria in the soil has resulted in major economic benefit for Brazil. Another local scientist, but of international stature.

\section{Other Cases from Brazil}

A fourth case (POLATI; CARDOSO, 2017) begins with Arthur Eddington and his now famous inquiry into the gravitational bending of light according to Einstein's theory of general relativity. Relevant measurements could be taken during a full solar eclipse, and one was due soon in 1919. As a Quaker, Eddington also wanted to promote post-war amity and cooperation by mounting an international science expedition. This is where student inquiry begins. Of course, the pathway of the eclipse must be determined first, and it reveals a swath through Brazil. But what is an appropriate observation site? Students must create a list of relevant criteria, such as favorable weather conditions, proximity to a port (to enable transport of all the telescopic equipment), and so forth. (Again, the concrete materiality matters here just as much 
as the theoretical design, easily sketched on a board.) Eddington consults an astronomer in Brazil, Henry Morize (Figure 8), and students take his role in choosing a location. As is now well known, he recommended a location in Sobral (Figure 9). The case also allows students to consider the results and the errors introduced by problems with the telescopic equipment. Further, how will all this be communicated to the public? Ultimately, with data also from Africa, Eddington announces the dramatic confirmation of Einstein's theory and the news appears on the front page of major newspapers worldwide. A major discovery, with Brazilians being significant contributors. The local connection makes the science a bit more approachable, and helps motivate a historical perspective into the nature of scientific practice.

Figure 8. Henry Morize, Brazilian astronomer who worked with Arther Eddington in 1918-19.

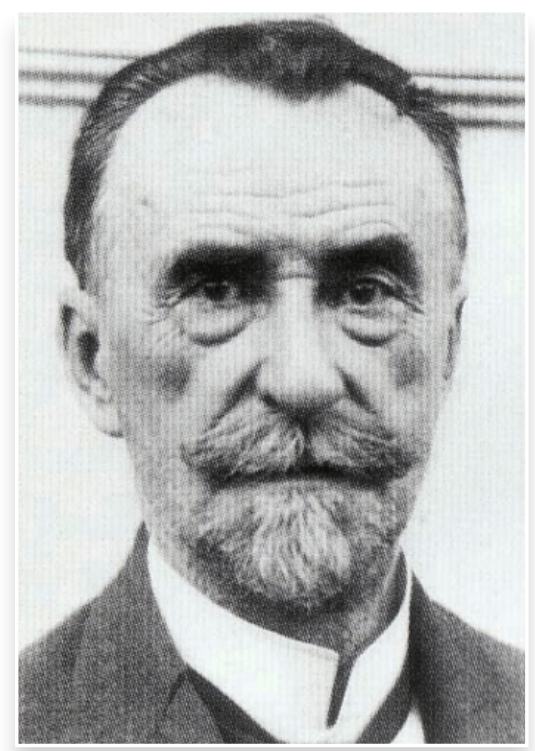


Figure 9. Site of the 1919 solar eclipse observation in Sobral, Brazil.

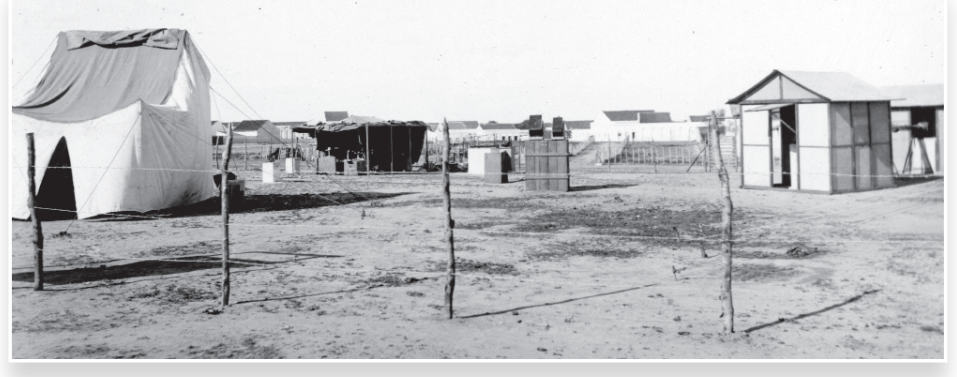

Finally, I mention only briefly the case of evolutionary biologist and geneticist Theodius Dobzhansky (de Oliveira Gomes \& de Moura Silva, in press). Dobzhansky was instrumental in integrating modern evolutionary studies with population genetics. He was invited to Brazil and chose to study wild fruit flies there. In several visits over many years, working with colleagues there, he collected important evidence on the genetics of evolving populations. At the same time, he helped the University of Sao Paulo establish its Genetics Department (Figure 10).

Figure 10. Geneticist Theodosius Dobzhansky (right) with Brazilian colleagues in the 1960s: Mario G. Ferri, Antonio Brito da Cunha and André Dreyfus (courtesy Museu da Genetica, University of Rio Grande do Sul).

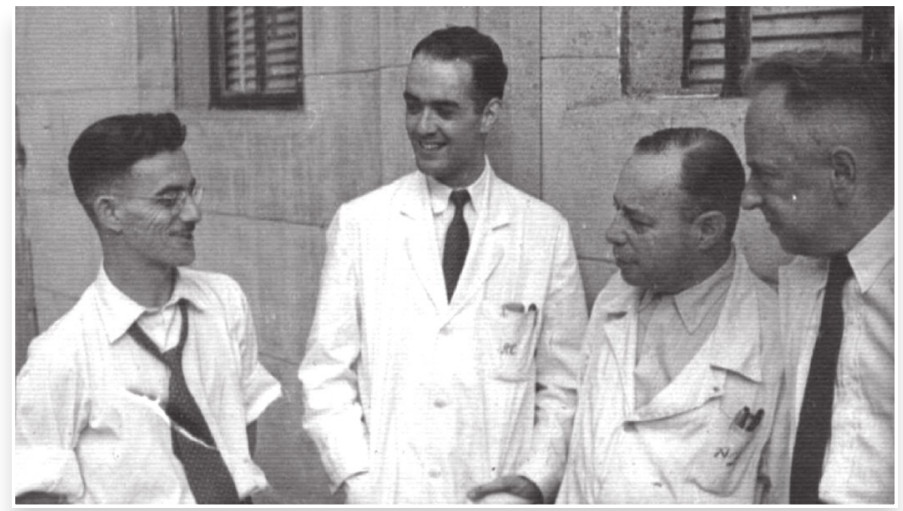




\section{Heroes and Myth-Conceptions}

All these cases highlight Brazilian scientists. That makes the history a more attractive resource to the typical Brazilian teacher (at least). Yet at the same time, a local or regional focus carries certain risks. Too eager for pride, one can easily overstate the importance of some scientific discovery and thereby dilute authentic lessons about the nature of science. But the cases above were selected precisely because they also exhibited global significance: they are just as valuable in the U.S., Canada, Germany, Greece, or elsewhere, where they can help profile the global nature of contributions to science. What matters is that the problems are significant, the narratives compelling, and the nature of science lessons clear and insightful.

Such cases are also vulnerable in another way. A common tendency of story-telling among novices is to amplify the heroic and nationalistic elements, creating monumental and unrealistic images of scientists. That is, they may easily succumb to myth-conceptions, pseudohistory and unfruitful rational reconstructions (ALLCHIN, 2000; 2003; 2004; 2006). When that happens, historical cases fail to render the nature of science faithfully. So a focus on local heroes should be balanced with a healthy historical realism to portray NOS authentically (ALLCHIN, 2000; HEERING, 2011). One should honestly acknowledge scientific errors, lapses in scientific integrity or research ethics, and personality flaws. Heroes need not be perfect to be heroes. Indeed, utopian "role models" typically impress students as unachievable. By contrast, realistic profiles of scientists become motivational as "real models." Also, given an important discovery as a benchmark, one can safely highlight the role of historical contingency, chance encounters, or accident. One need not misleadingly attribute the achievement wholly to one person's abilities. Equally, one should take the opportunity of the secure image of a central 
hero to underscore the role of others who contributed: research is inevitably a communal effort. Morize is an important part of Eddington's story. Nevertheless, when properly contextualized and enriched with inquiry questions, local historical cases can offer an attractive opportunity for teachers to engage students in lessons about the nature of science.

\section{References}

ALLCHIN, D. How not to teach historical case studies in science. Journal of College Science Teaching, v.30, p.33-37, 2000.
ALLCHIN, D. Scientific myth-conceptions. Science Education, v.87, p.329-351, 2003.

ALLCHIN, D. Pseudohistory and pseudoscience. Science \& Education, v.13, p.179-195, 2004.
ALLCHIN, D. Lawson's shoehorn, reprise. Science \& Education, v.15, p.113-120, 2006.

ALLCHIN, D. The Minnesota Case Study Collection: New historical inquiry cases for nature of science education. Science $\&$ Education, v.21, p.1263-1282, 2012.

ALLCHIN, D. Teaching the nature of science: Perspectives and resources. St. Paul, MN: SHiPS Education Press, 2013.

ALLCHIN, D. From snakebites to serpentariums. American Biology Teacher, v.79, p.428-430, 2017.

ALLCHIN, D. From history to teaching nature of science.

Cadernos de História da Ciência, v.13, n.2, in press 1. 
ALLCHIN, D. Historical inquiry cases for nature of science learning. Cadernos de História da Ciência, v.13, n.2, in press 2.

ALLCHIN, D.; ANDERSEN, H. M.; NIELSEN, K.

Complementary approaches to teaching nature of science: integrating student inquiry, contemporary cases and historical cases in classroom practice. Science Education, v.98, p.461-486, 2014.

AZEVEDO, N. H.; DEL CORSO, T. "A doença dos trabalhadores da estrada de ferro": Uma narrativa histórico investigativa e suas potencialidades para explorar aspectos de natureza da ciência.

Cadernos de História da Ciência, v.13, n.2, in press.

BRUNEAU, O. et al.(eds.) Innovative Methods for Science Education: History of Science, ICT and Inquiry Based Science Teaching. Berlin: Frank \&Timme, 2012.

CLOUGH, M. F. Learners' responses to the demands of conceptual change: Considerations for effective nature of science instruction. Science \& Education, v.15, n.5, p.463-94, 2006.

CLOUGH, M. P. The story behind the science: Bringing science and scientists to life in post-secondary science education. Science \& Education, v.20, n.7-8, p.701-717, 2011.

CONANT, J. B. On understanding science. New Haven, CT: Yale University Press, 1947.

CONANT, J. B. (ed.). Harvard case histories in experimental science. Cambridge, MA: Harvard University Press, 1957.

DENG, F. et al., Students' views of the nature of science: A critical review of research. Science Education, v.95, p.961-99, 2011. 
FARBER, P. Teaching evolution and the nature of science. American Biology Teacher, v.65, p.347-54, 2003.

FLOWER, M. Conceiving science education as a practice of technoscientific practice. In: Finley, F. et al., (eds.), Proceedings of the Third International History, Philosophy, and Science Teaching Conference, p.389-409. Minneapolis, MN: University of Minnesota Office of Continuing Education, 1995.

HAGEN, J. B.; ALLCHIN, D.; SINGER, F. Doing biology. Glenview, IL: HarperCollins, 1996.

HEERING, P. False friends: What makes a story inadequate for science teaching? Interchange, v.41, p.323-333, 2011.

HENKE, A.; HÖTTECKE, D. Physics teachers' challenges in using history and philosophy of science in teaching. Science $\boldsymbol{Q}$ Education, v.24, n.4, p.349-385, 2015.

HERREID, C. F. The interrupted case method. Journal of College Science Teaching, v.35, n.2, p.4-5, 2005.

HIPST [History and Philosophy in Science Teaching Consortium]. (2008). Theoretical basis of the HIPST Project. http://hipst.eled.auth.gr/hipst_htm/theory_complete.htm. Accessed 17 April 2019.

HODSON, D. Towards scientific literacy. Rotterdam, The Netherlands: Sense, 2008

HÖTTECKE, D.; SILVA, C. C. Why implementing history and philosophy of science in school science education is a challenge: An analysis of obstacles. Science \& Education, v.20, p.293-316, 2012. 
HOWE, E. M. Addressing nature-of-science core tenets with the history of science: An example with sickle-cell anemia. American Biology Teacher, v. 69, p. 467-72, 2007.

IRWIN, A. R. Historical case studies: Teaching the nature of science in context. Science Education, v.84, p.5-26, 2000.

KLASSEN, S. The application of historical narrative in science learning: The Atlantic cable story. Science \& Education, v.16, n.35, p.335-352, 2007.

KLOPFER, L.E. The teaching of science and the history of science. Journal of Research in Science Teaching, v.6, p.87-95, 1969.

LATOUR, B. Science in action. Cambridge, MA: Harvard University Press, 1987.

MCCOMAS, W. F.; OLSON, J. K. The nature of science in international science education standards documents. In: MCCOMAS, W.F. (Ed.), The nature of science in science education:

Rationales and strategies. Dordrecht, The Netherlands: Kluwer, 1998, p.41-52.

MONK, M., OSBORNE, J. Placing the history and philosophy of science on the curriculum: a model for the development of pedagogy. Science Education, v. 81, p.405-24, 1997.

NASH, L. K. An historical approach to the teaching of science. Journal of Chemical Education, v.28, p.146-151, 1951.

NATIONAL RESEARCH COUNCIL. National science education standards. Washington, DC: National Academy Press, 1996. 
NGSS LEAD STATES. Next generation science standards: For states, by states. Washington, DC: The National Academies Press, 2013.

OSBORNE, J. et al., What "ideas-about-science" should be taught in school science? A Delphi study of the expert community. Journal of Research in Science Teaching, v.40, p.692-720, 2003.

OECD. PISA for development assessment and analytical framework: Reading, mathematics and science, preliminary version. Paris: OECD Publishing, 2017.

DE OLIVEIRA GOMES, F.; DE MOURA SILVA, G. A genética no Brasil entre 1934 e 1956: um estudo de caso histórico para o ensino de natureza da ciência. [Genetics in Brazil between 1934 and 1956: a historical case study for teaching nature of science.] Cadernos de História da Ciência, v.13, n.2, in press.

DE OLIVEIRA GOMES, F.; DE MOURA SILVA, G. Dreyfus, Dobzhansky e a Genética no Brasil. Cadernos de História da Ciência, v.13, n.2, in press.

POLATI, F.; CARDOSO, D. Arthur S. Eddington provou a teoria da relatividade geral? Uma proposta de atividade histórica para discutir a natureza da ciência. XXII Simpósio Nacional de Ensino de Física - SNEF. http://www1.sbfisica.org.br/eventos/snef/xxii/ sys/resumos/ T1326-1.pdf , 2017. (Accessed April 18, 2019).

PONCE, R.; SIMONETTI, U. Johanna Döbereiner, soil bacteria and plants. (n.p.)

RICCI, F. P.; TEIXEIRA, K. K. S.; DE OLIVEIRA, A. D. O estudo do caso histórico de Vital Brazil em sala de aula: uma 
ferramenta para investigar a visão dos alunos sobre os desafios enfrentados durante uma pesquisa cientifica. [The study of the historical case of Vital Brazil in the classroom: a tool to investigate students' views on the challenges faced during a scientific research.] Cadernos de História da Ciência, v.13, n.2, in press.

RICCI, F. P.; DE OLIVEIRA, A. D. Vital Brazil e as mordidas de cobras. Cadernos de História da Ciência, v.13, n.2, in press.

RUDGE, D.W.; HOWE, E.M. An explicit and reflective approach to the use of history to promote understanding of the nature of science. Science \& Education, v.18, p.561-80, 2009.

RUTHERFORD, F. J.; AHLGREN, A. Science for all Americans. Oxford, England: Oxford University Press, 1990.

STINNER, A. Contextual settings, science stories, and large context problems: Toward a more humanistic science education. Science Education, v.79, n.5, p.555-81, 1995.

STINNER, A. et al. The renewal of case studies in science education. Science \& Education, v.12, n.7, p.617-43, 2003. 